\title{
Essential Oil of One of the Iranian Skullcaps
}

Alireza Ghannadi* and Iraj Mehregan

Department of Pharmacognosy, School of Pharmacy and Pharmaceutical Sciences, Isfahan University of Medical Sciences, Isfahan 81746-73461, Iran. Fax: +98311-6680011 E-mail: ghannadi@pharm.mui.ac.ir

* Author for correspondence and reprint requests

Z. Naturforsch. 58c, 316-318 (2003); received December 20, 2002/January 17, 2003

The hydro-distilled essential oil from dried aerial parts of one of widespread Iranian skullcaps, Scutellaria pinnatifida A. Hamilt. ssp. alpina (Bornm.) Rech. grown in Khorassan province was analyzed by GC and GC/MS. Thirty components were characterized representing $93.8 \%$ of the total components detected. The major components of the oil were germacrene-D (39.7\%) and beta-caryophyllene (15.0\%).

Key words: Scutellaria pinnatifida ssp. alpina, Essential Oil, Germacrene-D

\section{Introduction}

The skullcaps, belonging to Scutellaria genus, Scutellaroideae tribe, Lamiaceae family, have been distributed in some parts of the world (Evans, 1989; Rechinger, 1982; Zargari, 1990). There are about 300 known species belonging to this genus (Evans, 1989). The Iranian flora comprises more than 20 species of Scutellaria and one of them is Scutellaria pinnatifida A. Hamilt. ssp. alpina (Bornm.) Rech. This plant which is widespread in several regions of Iran, is growing in rich woods, thickets, bluffs, along roadsides and on the banks of rivers and lakes (Mozaffarian, 1996; Rechinger, 1982). The Persian name of the plant is "Boshghabi" that means "dish like" (Mozaffarian, 1996). Skullcaps are well known among people as powerful medicinal herbs. These plants are used in traditional and folk medicines of different parts of the world for the treatment of hypertension, arteriosclerosis, inflammatory diseases, hepatitis, allergy, cancer and diarrhea and have sedative, antioxidant, antithrombotic, cytotoxic, antispasmodic, antimicrobial and antiviral properties (Duke, 1989; Graham et al., 2000; Hui et al., 2002; Kim et al., 2001; Stojakowska and Kisiel, 1999; Zargari, 1990). There are some reports on the phytochemical analysis of species belonging to Scutellaria found in the literature but only a very small number of these species have so far been studied chemically for their essential oils. Phytochemical studies on skullcaps revealed that flavonoids, essential oils, iridoids, tannins, lignins, phenolics, diterpenes and triterpenes were present in different parts of the plant (Duke, 1989; Ezer et al., 1998; Hui et al., 2002; Kim et al., 2001; Skaltsa et al., 2000; Stojakowska and Kisiel, 1999; Yaghmai, 1988; Zargari, 1990). To the best of our knowledge, there is no previous report on the chemical composition of the essential oil of S. pinnatifida ssp. alpina. Therefore the present paper deals with the detailed analysis of the oil by capillary GC and GC/MS. Aerial parts of this plant have been used in some parts of Iran as gastrointestinal remedy.

\section{Methods and Materials}

\section{Plant material}

Aerial parts of wild-growing S. pinnatifida ssp. alpina were collected during the full flowering period from an area between Bojnoord and Shoghan (Khorassan Province, Eastern North of Iran) at an altitude of ca. $2150 \mathrm{~m}$ in June 2002. The plant identity was confirmed by the Herbarium Department of School of Pharmacy, Mashad University of Medical Sciences, Mashad, Iran. A voucher specimen of the plant (HN-874) was deposited in this Herbarium.

\section{Essential oil isolation}

The air-dried aerial parts of the plant were powdered and the volatile fraction was isolated by hy- 
drodistillation for $3 \mathrm{~h}$ (British Pharmacopoeia, 1998). The oil was dried over anhydrous sodium sulfate and stored at $4{ }^{\circ} \mathrm{C}$.

\section{Essential oil analysis}

The oil was analyzed by GC and GC/MS. GC analysis was carried out on a Perkin-Elmer gas chromatograph model 8500, equipped with a FID detector and a BP-1 capillary column $(30 \mathrm{~m} \times$ $0.25 \mathrm{~mm}$, film thickness $0.25 \mu \mathrm{m}$ ). The operating conditions were as follows: carrier gas, helium with a flow rate of $2 \mathrm{ml} / \mathrm{min}$; column temperature, $60-$ $275^{\circ} \mathrm{C}$ at $4{ }^{\circ} \mathrm{C} / \mathrm{min}$; injector and detector temp, $280{ }^{\circ} \mathrm{C}$; volume injected, $0.1 \mu \mathrm{l}$ of the oil; split ratio, 1:50.

GC/MS analysis was performed on a Hewlett Packard 6890 mass selective detector coupled with a Hewlett Packard 6890 gas chromatograph, equipped with a cross-linked 5\% PH ME siloxane HP-5MS capillary column $(30 \mathrm{~m} \times 0.25 \mathrm{~mm}$, film thickness $0.25 \mu \mathrm{m}$ ) and operating under the same conditions as described above. The MS operating parameters were as follows: ionization potential, $70 \mathrm{eV}$; ionization current, $2 \mathrm{~A}$; ion source temperature, $200{ }^{\circ} \mathrm{C}$; resolution, 1000 . Identification of components in the oil was based on GC retention indices relative to $n$-alkanes and computer matching with the WILEY 275.L library, as well as by comparison of the fragmentation patterns of the mass spectra with those reported in the literature (Adams, 1995; Mclafferty and Stauffer, 1991; Sandra and Bicchi, 1987; Swigar and Silverstein, 1981). The relative percentage of the oil constituents was calculated from the GC peak areas.

\section{Results and Discussion}

Aerial parts of $S$. pinnatifida ssp. alpina yielded $0.2 \%$ of a yellowish oil with a pleasant aroma. Thirty components were characterized, representing $93.8 \%$ of the total oil components detected. These are listed in Table I with their percentage composition. The major constituents of the oil were germacrene-D (39.7\%), beta-caryophyllene $(15.0 \%)$, delta-cadinene $(5.3 \%)$ and alpha-copaene $(5.0 \%)$. Other components were present in amounts less than $5 \%$. The oil was rich in hydrocarbon sesquiterpenes. The monoterpene portion of the essential oil accounts for only $1.9 \%$. Many of the unidentified compounds were present
Table I. Composition of the essential oil of Scutellaria pinnatifida ssp. alpina.

\begin{tabular}{|c|c|c|}
\hline Compound & Percentage & $\begin{array}{l}\text { Retention } \\
\text { Index }\end{array}$ \\
\hline Limonene & 0.2 & 1027 \\
\hline 1,8-Cineole & 0.1 & 1030 \\
\hline$\gamma$-Terpinene & 0.5 & 1058 \\
\hline Linalool & 1.1 & 1096 \\
\hline$\alpha$-Longipinene & 0.8 & 1348 \\
\hline$\alpha$-Copaene & 5.0 & 1375 \\
\hline$\beta$-Bourbonene & 0.9 & 1382 \\
\hline$\beta$-Cubebene & 0.4 & 1389 \\
\hline$\alpha$-Gurjunene & 0.3 & 1406 \\
\hline$\beta$-Caryophyllene & 15.0 & 1416 \\
\hline trans- $\alpha$-Bergamotene & 0.7 & 1434 \\
\hline Aromadendrene & 0.9 & 1438 \\
\hline$\alpha$-Humulene & 0.7 & 1454 \\
\hline trans- $\beta$-Farnesene & 2.0 & 1457 \\
\hline Alloaromadendrene & 0.3 & 1462 \\
\hline Germacrene-D & 39.7 & 1478 \\
\hline Bicyclogermacrene & 4.8 & 1494 \\
\hline$\beta$-Himachalene & 1.9 & 1501 \\
\hline$\beta$-Bisabolene & 0.2 & 1511 \\
\hline$\gamma$-Cadinene & 1.8 & 1516 \\
\hline cis- $\gamma$-Bisabolene & 0.5 & 1518 \\
\hline$\delta$-Cadinene & 5.3 & 1527 \\
\hline$\alpha$-Cadinene & 0.6 & 1540 \\
\hline$\alpha$-Calacorene & 0.4 & 1543 \\
\hline Germacrene-B & 0.9 & 1558 \\
\hline Spathulenol & 2.0 & 1578 \\
\hline Caryophyllene oxide & 2.5 & 1584 \\
\hline Viridiflorol & 0.8 & 1594 \\
\hline$\alpha$-Muurolol & 1.3 & 1651 \\
\hline$\alpha$-Cadinol & 2.2 & 1656 \\
\hline
\end{tabular}

in trace amounts. Contrary to the earlier reports that linalool and trans-nerolidol were present in the oil of S. albida ssp. albida (Skaltsa et al., 2000) and alpha-cadinene, calamenene and beta-elemene in the oil of S. lateriflora (Yaghmai, 1988) as major constituents, in the present study some of these compounds could not be found. Linalool and alpha-cadinene contents of this oil were $1.1 \%$ and $0.6 \%$ respectively. According to our literature surveys germacrene-D, beta-caryophyllene, delta-cadinene and alpha-copaene have been previously detected in other taxa belonging to Lamiaceae family but their predominance has not been recorded within this family. Germacrene-D, the most prominent component of the oil has been found in relatively high amounts in the essential oils of some other taxa of Lamiaceae family such as Hyssopus, Teucrium, Acinus and Micromeria (Blazevic et al., 1992; Fleisher and Fleisher, 1991; Kerrola et al., 1994; Velasco-Negueruela et al., 1993). Beta- 
caryophyllene, which was found as a second major component of the oil, has been reported in the several oils of Lamiaceae family species (Bourrel et al., 1993; Duke, 1989).

\section{Acknowledgments}

We are grateful to Dr. Seyed Ahmad Emami (Department of Pharmacognosy, Faculty of Pharmacy, Mashad University of Medical Sciences, Mashad, Iran) for his help in gathering of plant material.
Adams R. P. (1995), Identification of Essential Oil Components by Gas Chromatography/Mass Spectroscopy. Allured Publishing Co., Carol Stream, pp. 94-358.

Blazevic N., Kalodera Z., Petricic J., and Plazibat M. (1992), Essential oil content and composition of Teucrium arduini L. J. Essent. Oil Res. 4, 223-225.

Bourrel C., Perineau F., Michel G., and Bessiere J. M. (1993), Catnip (Nepeta cataria L.) essential oil analysis of chemical constituents, bacteriostatic and fungistatic properties. J. Essent. Oil Res. 5, 159-167.

British Pharmacopoeia (1998), Vol. 2. HMSO, London, pp. A137-A138

Duke J. A. (1989), CRC Handbook of Medicinal Herbs. CRC Press, Boca Raton, pp. 332-333, 412-413, 420422, 440.

Evans W. C. (1989), Trease and Evans' Pharmacognosy, $13^{\text {th }}$ ed. Bailliere Tindall, London, pp. 216-217.

Ezer N., Akcos Y., and Rodriguez B. (1998), Neo-clerodane diterpenoids from Scutellaria orientalis subsp. sintenisii. Phytochemistry 49, 1825-1827.

Fleisher Z., and Fleisher A. (1991), The essential oil of Micromeria fruticosa (L.) Druce ssp. barbata (Boiss et Ky.), P. H. Davis-aromatic plants of the holy land and the Sinai. Part VII. J. Essent. Oil Res. 3, 477-479.

Graham J. G., Quinn M. L., Fabricant D. S., and Farnsworth N. R. (2000), Plants used against cancer - an extension of the work of Jonathan Hartwell. J. Ethnopharmacol. 73, 347-377.

Hui K. M., Huen M. S., Wang H. Y., Zheng H., Sigel E., Baur R., Ren H., Li Z. W., Wong J. T., and Xue H (2002), Anxiolytic effect of wogonin, a benzodiazepine receptor ligand isolated from Scutellaria baicalensis Georgi. Biochem. Pharmacol. 64, 1415-1424.

Kerrola K., Galambosi B., and Kallio H. (1994), Volatile components and odor intensity of four phenotypes of Hyssop (Hyssopus officinalis L.). J. Agric. Food Chem. 42, 776-781.
Kim B. R., Kim D. H., Park R., Kwon K. B., Ryu D. G., Kim Y. C., Kim N. Y., Jeong S, Kang B. K., and Kim K. S. (2001), Effect of an extract of the root of Scutellaria baicalensis and its flavonoids on aflatoxin $\mathrm{B}_{1}$ oxidizing cytochrome P450 enzymes. Planta Med. 67, 396-399.

Mclafferty F. W., and Stauffer D. B. (1991), The Important Peak Index of the Registry of Mass Spectral Data, Vol. 1. John Wiley \& Sons, New York, pp. 141-749.

Mozaffarian V. (1996), A Dictionary of Plant Names. Farhang Moa'ser, Tehran, pp. 497-499.

Rechinger K. H. (1982), Flora Iranica, No. 150. Akademische Druck- u. Verlagsanstalt, Graz, pp. 2, 48, 78.

Sandra P., and Bicchi C. (1987), Capillary Gas Chromatography in Essential Oil Analysis. Dr. A. Huethig, Heidelberg, pp. 259-274, 287-328.

Skaltsa H. D., Lazari D. M., Mavromati A. S., Tiligada E. A., and Constantinidis T. A. (2000), Composition and antimicrobial activity of the essential oil of Scutellaria albida ssp. albida from Greece. Planta Med. 66, 672-674.

Stojakowska A., and Kisiel W. (1999), Secondary metabolites from a callus culture of Scutellaria columnae. Fitoterapia 70, 324-325.

Swigar A. A., and Silverstein R. M. (1981) Monoterpenes-Infrared, Mass, Proton-NMR, Carbon-NMR Spectra and Kovats Indices. Aldrich Chemical Company Inc., Madison, pp. 3-121.

Velasco-Negueruela A., Perez-Alonso M. J., Jimenez S. M., and Garcia F. M. (1993), The volatile constituents of Acinus alpinus (L.) Moench ssp. meridionalis (Nyman). P. W. Ball growing in Spain. Flavour Fragr. J. 8, 127-130.

Yaghmai M. (1988), Volatile constituents of Scutellaria lateriflora L. Flavour Fragr. J. 3, 27-31.

Zargari A. (1990), Medicinal Plants, Vol. 4. Tehran University Publications, Tehran, pp. 148-150. 